\title{
TITLE:
}

\section{THE ZOOGEOGRAPHICAL ASPECTS OF THE JAPAN SEA -PART III-}

AUTHOR(S):

Nishimura, Saburo

CITATION:

Nishimura, Saburo. THE ZOOGEOGRAPHICAL ASPECTS OF THE JAPAN SEA -PART III-. PUBLICATIONS OF THE SETO MARINE BIOLOGICAL LABORATORY 1966, 13(5): 365-384

\section{ISSUE DATE:}

1966-02-25

URL:

http://hdl.handle.net/2433/175417

RIGHT: 


\title{
THE ZOOGEOGRAPHICAL ASPECTS OF THE JAPAN SEA PART III'
}

\author{
SABURo NISHIMURA
}

Seto Marine Biological Laboratory, Sirahama

With Text-figures 24-27

\section{CONTENTS}

Page

3. Peculiarities of Animal Distribution in the Japan Sea (continued) ....... 365

3. 9. Vertical Segregation of Northern and Southern Elements ............ 365

3. 10. Faunal Zonation on the "Okaba" and "Taraba" Grounds ............ 372

\section{Peculiarities of Animal Distribution in the Japan Sea (continued)}

\subsection{Vertical Segregation of Northern and Southern Elements}

As mentioned previously (Chapter 2 and Section 3. 1), it is one of the most remarkable features of the fauna of the Japan Sea that both northern and southern elements are thriving in a kind of "intermingling" or "coexisting" state over a large part of the sea. This may be true so far as concerned with the horizontal pattern of animal distribution. But if the distribution is analysed on the three-dimensional basis, then the above expression is no longer acceptable; the northern and southern elements are sharply segregated from each other vertically, respectively inhabiting quite different levels within the Japan Sea, as will be shown next.

Trawlers in the southern and southeastern parts of the present marginal sea clearly classify their fishing area into two different grounds, namely, "okaba" and "taraba". The former, which means the landward ground in Japanese, is the area spreading over the continental shelf and shallower than $150 \mathrm{~m}$; while the latter, meaning the cod ground in Japanese, is the area extending on the continental slope over $150-200 \mathrm{~m}$ in the depth. These two grounds hold respectively their own characteristic bottom animal communities differing from each other so markedly (ОКACHI 1954; WA TANABE et al. 1960; Ouchi \& Ogata 1962 ; etc.) (Fig. 24).

1) Contributions from the Seto Marine Biological Laboratory, No. 446.

Publ. Seto Mar. Biol. Lab., XIII (5), 365-384, 1966. (Article 20) 


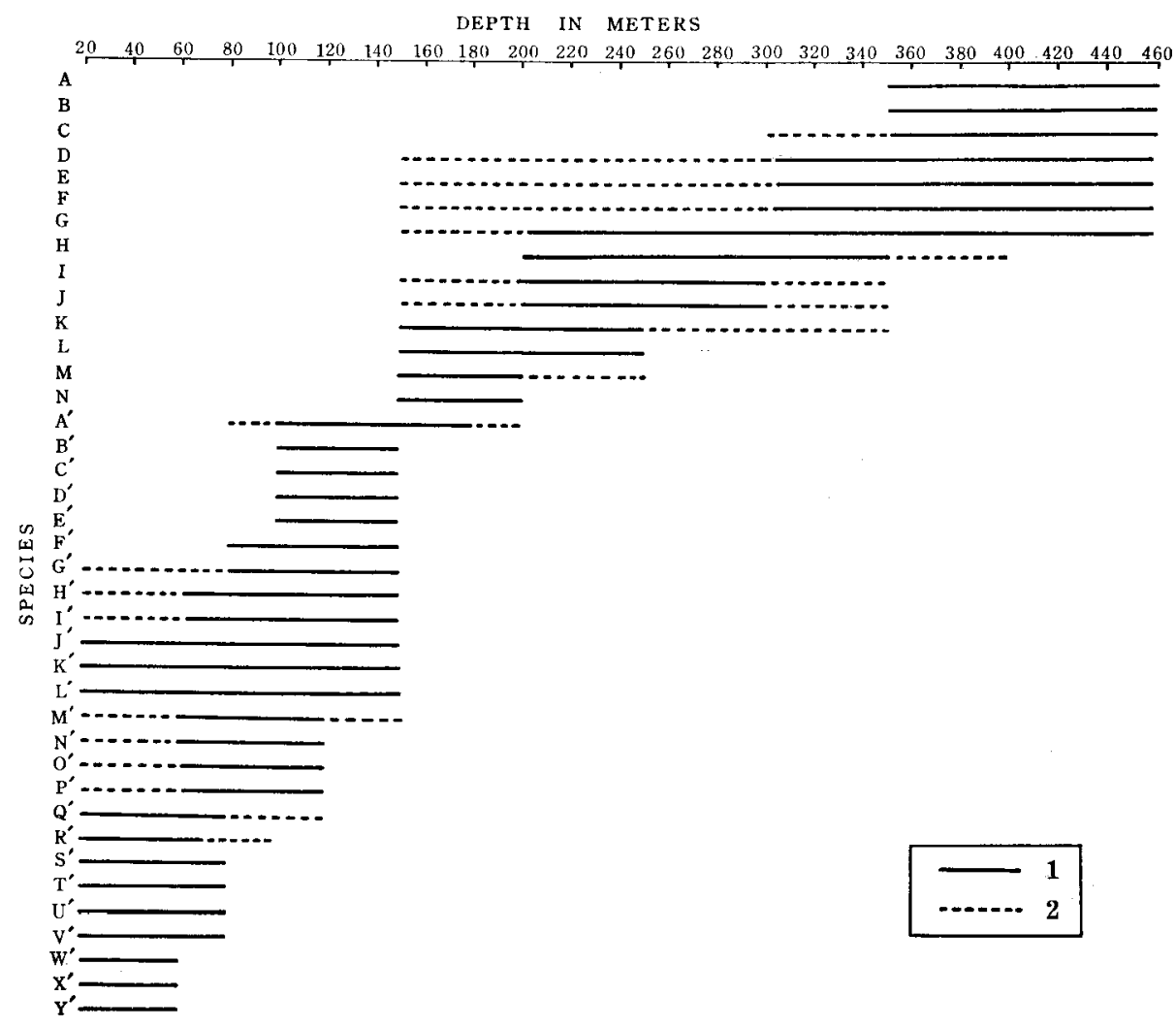

Fig. 24. Depth ranges of some representative demersal fishes on the "okaba" and "taraba" grounds in the eastern Japan Sea off the coast of Niigata and Yamagata Prefectures, as compiled from various sources. 1.-Main range of adult individuals; 2.-Range of occasional occurrences of adult individuals. The species are indicated by alphabetical letters as: A.-Lumpenus macrops; B.-L. gracilis; C.-Malacocottus gibber; D.-Allolepis hollandi ; E.Lycodes tanakai; F.-L. nakamurai; G.-Hippoglossoides dubius; H.-Theragra chalcogramma ; I.-Gadus morhua macrocephalus; J.-Arctoscopus japonicus; K.-Glyptocephalus stelleri ; L.Pleurogrammus azonus; M.-Cleisthenes pinetorum herzensteini ; N.-Stichaeus grigorjewi ; $\mathrm{A}^{\prime}-$ Glossanodon semifasciatus; $\mathrm{B}^{\prime}$.-Döderleinia berycoides; $\mathrm{C}^{\prime}$. -Eopsetta grigorjewi; $\mathrm{D}^{\prime}$.-Tanakius kitaharai; $\mathrm{E}^{\prime}$.-Atopocottus tribranchius; $\mathrm{F}^{\prime}$.-Pseudorhombus pentophthalmus; $\mathrm{G}^{\prime}$-Zeus japonicus; $\mathrm{H}^{\prime}$.-Trachurus japonicus; $\mathrm{I}^{\prime}$.-Uranoscopus japonicus; $\mathrm{J}^{\prime}$-Limanda herzensteini ; $\mathrm{K}^{\prime}$.-Hexagrammos otaki; $\mathrm{L}^{\prime}$-Paralichthys olivaceus; $\mathrm{M}^{\prime}$.-Chaeturichthys sciistius; $\mathrm{N}^{\prime}$--Saurida undosquamis; $\mathrm{O}^{\prime}$.-Chrysophrys major; $\mathrm{P}^{\prime}$.-Lepidotrigla kishinouyei; $\mathrm{Q}^{\prime}$.-Upeneus bensasi; $\mathrm{R}^{\prime}$.-Callionymus richardsoni ; $\mathrm{S}^{\prime}$.-Chaeturichthys hexanema; $\mathrm{T}^{\prime}$.-Pseudorhombus cinnamoneus ; $\mathrm{U}^{\prime} .-$ Aseraggodes kobensis; $\mathrm{V}^{\prime}$.-Apogon lineatus; $\mathrm{W}^{\prime}$--Leiognathus rivulatus; $\mathrm{X}^{\prime}$.-Laeops lanceolatus ; $Y^{\prime}$.-Heteromycteris japonicus.

The species $\mathrm{A}$ to $\mathrm{N}$ are representatives of the "taraba" ground, while the species $\mathrm{A}^{\text {" }}$ to $\mathrm{Y}^{\prime}$ are inhabitants of the "okaba" ground. It is clearly shown that the species of respective grounds are, except for $\mathrm{A}^{\prime}$ (Glossanodon semifasciatus), sharply segregated from each other with the boundary near the depth of $150 \mathrm{~m}$ : the "taraba" ground species inhabit the bottom deeper than $150 \mathrm{~m}$, while the "okada" ground species are all living on the level shallower than $120-150 \mathrm{~m}$. The parts of the sea deeper than $460 \mathrm{~m}$ and shallower than $20 \mathrm{~m}$ are omitted in this figure. 
These animal communities are quite different primarily in the climatological aspects: the communities of the "okaba" are composed mainly of southern, tropical to warm-temperate elements in contrast to those inhabiting the "taraba" which are composed exclusively of northern, arctic to subarctic elements. For instance, among the fishes, the predominant constituents on the "okaba" ground include (1) the warm-temperate species like the cardinalfish Apogon lineatus, parrot-fish Oplegnathus fasciatus, argentine Glossanodon semifasciatus, jack mackerel Trachurus japonicus, sea-breams (Chrysophrys and Evynnis), serranid Döderleinia berycoides, blackfish Girella punctata, dragonets (Callinonymus), gobies (especially Chaeturichthys), leather-jacket Stephanolepis cirrhifer, bastard-halibut Paralichthys olivaceus, anglers (Lophius and Lophiomus), skates Raja kenojei and tengu, stingray Dasyatis akajei, etc., all of which are typically thriving in the south Japanese waters, (2) the subtropical species like the cardinal-fish Apogon semilineatus, gurnards (Lepidotrigla), pony-fish Leiognathus rivulatus, serranid Niphon spinosus, rainbow-fish Halichoeres tenuispinis, petrale sole Eopsetta grigorjewi, tongue sole Cynoglossus robustus, etc., which are found in the area from southern Japan to Formosa or the Philippines, and even (3) the tropical species such as the goat-fish Upeneus bensasi, red gurnard Chelidonichthys kumu, flathead Platycephalus indicus, spinefoot Siganus fuscescens, whiting Sillago sihama, croaker Argyrosomus argentatus, barracuda Sphyraena pinguis, flounder Pseudorhombus pentophthalmus, sole Zebrias zebra, gummy-shark Mustelus manazo, etc., which are widely distributed in the IndoWest Pacific region, especially in the East Indies, of ten reaching the Australian or Polynesian waters and the East African coast. Meanwhile, the "taraba" fauna is represented by the arctic-subarctic species such as the cod Gadus morhua macrocephalus, Alaska pollack Theragra chalcogramma, sandfish Arctoscopus japonicus, sea-poacher Percis japonica, skates Breviraja smirnovi and isotrachys, etc., which are widely distributed from the Japan Sea to the Okhotsk or the Bering Sea, and such as the various species of snailfishes (Liparis and Crystallias), sculpins (Myoxocephalus, Gymnocanthus, Icelus, Triglops, Dasycottus, Malacocottus, etc.) and eelpouts (Lycodes, Petroschmidtia, Davidijordania, Allolepis, etc.), dab Hippoglossoides dubius, plaice Limanda punctatissima, most of which are

Legend to Fig. 24 (continued).

The figure shows also that the species in either grounds may be further subdivided into several groups according to their vertical ranges of occurrence: on the "okaba" ground, four such groups are discernible - the first group, including species $Q^{\prime}$ to $Y^{\prime}$, indicate the vertical range shallower than $60-80 \mathrm{~m}$, the second including species $\mathrm{B}^{\prime}$ to $\mathrm{P}^{\prime}$ but $J^{\prime}, K^{\prime}$ and $L^{\prime}$ with the main range from $60-80 \mathrm{~m}$ to $150 \mathrm{~m}$, the third comprising species $\mathrm{J}^{\prime}, \mathrm{K}^{\prime}$ and $\mathrm{L}^{\prime}$ with the wide range extending on all the landward bottom down to $150 \mathrm{~m}$, and the last comprising solely species $A^{\prime}$ inhabiting $80-100 \mathrm{~m}$ to about $200 \mathrm{~m}$; while on the "taraba" ground, three such groups are discernible-the first group including species $\mathrm{K}$ to $\mathrm{N}$ with the range from about $150 \mathrm{~m}$ to $200-250 \mathrm{~m}$, the second comprising species $\mathrm{G}$ to $\mathrm{J}$ mainly from $200 \mathrm{~m}$ to $300-350 \mathrm{~m}$, and the last involving species $A$ to $F$ from the depths generally greater than $300-350 \mathrm{~m}$. The characters of these groups and further discussions are given in the text (p. $373 \mathrm{ff}$ ). 
limited within the Japan Sea but have their closest relatives, either ancestral forms or derivatives, in the most cold regions of the Okhotsk or the Bering Sea (Nishimura 1964c).

A similar segregation of northern and southern elements is observable in any other animal groups, too.

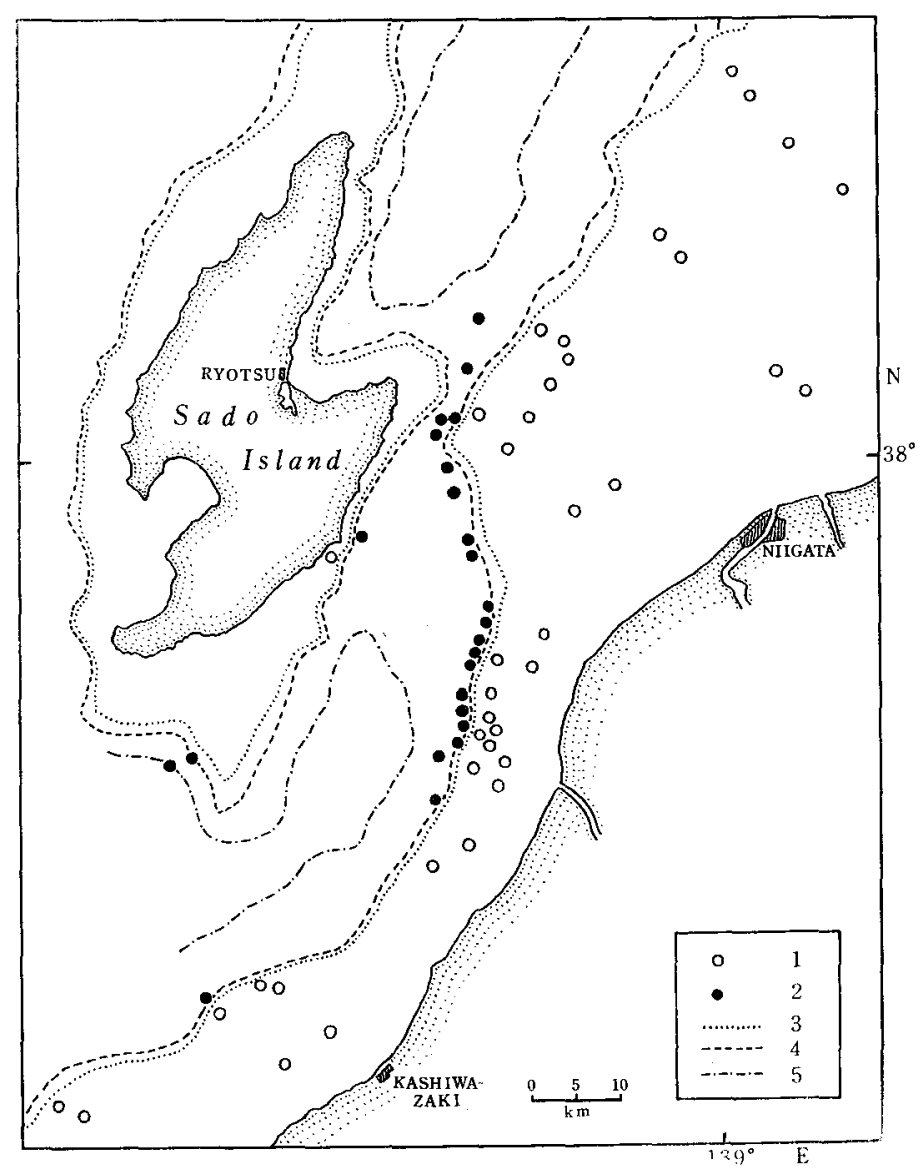

Fig. 25. Segregation of the "okaba" and "taraba" bottom faunas by bathymetric levels as revealed by the trawling experiments made in the period from January to March, 1953, in the Sado Straits in the eastern Japan Sea (Adapted from OKACHI 1954). 1.-Position where the "okaba" fauna was sampled; 2.-Position where the "taraba" fauna was sampled; 3, 4, 5.-The bathymetric lines of $150 \mathrm{~m}, 200 \mathrm{~m}$ and $500 \mathrm{~m}$, respectively.

The segregation is so sharp and distinct as to result hardly in any formation of the mixed fauna; we can judge the assignment of any trawled sample to either of the faunas, "okaba" or "taraba", at a glance. These faunas are so sharply separated from each other on the sea bottom around the boundary 
species given below were concentrated at the levels deeper than $200 \mathrm{~m}$ :
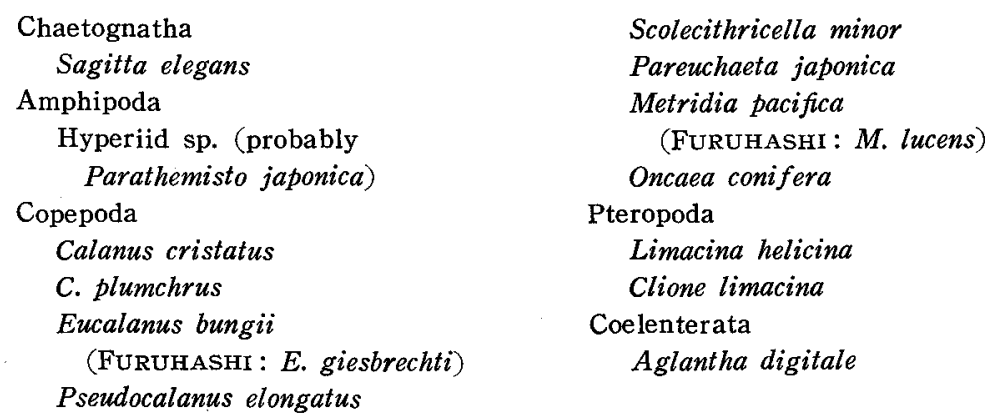

Some species occurred only in the middle 100-250 m layers; they were Fritillaria borealis of Tunicata, Sagitta serratodentata of Chaetognatha, Ctenocalanus vanus (FURUHASHI : Ct. longicornis) of Copepoda, and an agalmid siphonophore (probably Agalmopsis elegans). These are regarded as characteristic forms of the middle stratum in the southeastern part of the Japan Sea ${ }^{2}$.

Similar results were obtained by YAMAzI (1953) for the vertical distribution of plankton animals off the same district in the warmer seasons of 1950. In his paper, the following species were added to the warm-water zooplankters in the upper layers :

$\begin{array}{ll}\text { Appendicularia } & \text { Calanus sinicus } \\ \text { Oikopleura dioica } & \text { (YAMAZI : C. helgolandicus) } \\ \text { Chaetognatha } & \text { Neocalanus robustior } \\ \text { Sagitta enflata } & \text { Mecynocera clausi } \\ \text { S. crassa f. typica } & \text { Eucalanus attenuatus (see also } \\ \text { S. crassa f. naikaiensis } & \text { foot-note 2) } \\ \text { Copepoda } & \text { Euchaeta spp. } \\ \text { C. tenuicornis (see also foot-note 2) } & \text { Sapphirina spp. }\end{array}$

Of these, Oikopleura dioica and Sagitta crassa f. typica and f. naikaiensis are distinctly neritic forms (cf. Sections 3.3 and 3.7). These warm-water forms were collected from the upper $100 \mathrm{~m}$, and below $100-150 \mathrm{~m}$ only the cold-water forms were obtained. It is noticeable that the boundary between the vertical ranges of warm-water and cold-water planktons is found roughly at the same depth by which the bottom communities on the "okaba" and "taraba" grounds are segregated.

Then, it is the turn that the nektonic communities are referred to: in the offshore region of the Japan Sea during the season from spring to early summer, we can trace by an echogram vast shoals of the Alaska pollack Theragra chalcogramma, a subarctic gadoid fish, migrating at midwater layers,

2) According to my own observations, Calanus tenuicornis and Eucalanus attenuatus of Copepoda seem to be included in this middle-layer group, though they are originally subtropical forms (BRODSky 1950, 1959 ; see also PONOMAREVA 1959). 
somewhat fluctuating in depth according to localities but generally deeper than $130-150 \mathrm{~m}$ in the south of the polar front (Fig. 26), while the surface layer of the same region during the season is occupied by warm-temperate to subtropical nektonic animals like the saury Cololabis saira, stromateid fish Ocycrius japonicus, common puffer Fugu vermicularis porphyreus, common squid Todarodes pacificus, etc. (Fisheries Agency, Japan 1962a, 1962b).

Thus, it seems that within the Japan Sea the southern warm-water and the northern cold-water faunas are by no neans mingled together but fairly
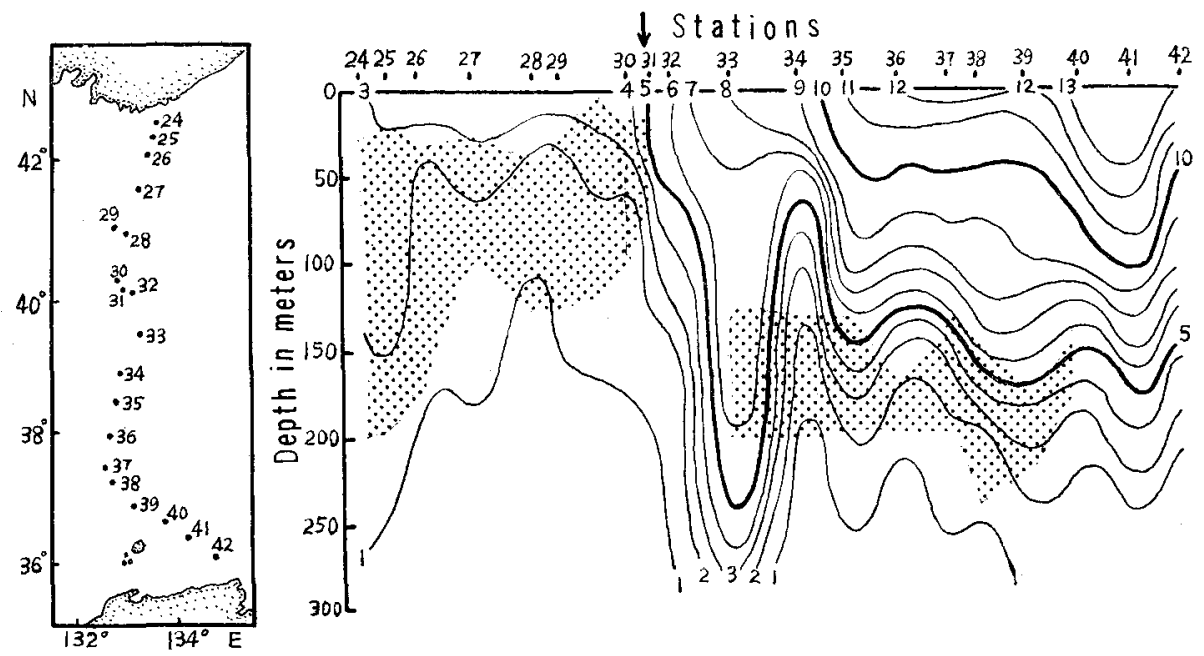

Fig. 26. The vertical distribution of pelagic shoals of the Alaska pollack Theragra chalcogramma in the offshore region of the Japan Sea as traced by an echogram during the cruise of the R. V. Heian Maru of the Kyoto Prefectural Fisheries Experimental Station in the period April 15 to 25, 1962. (From Fisheries Agency, Japan 1962b). The vertical range of the shoals is shown as dotted spaces together with isotherms and the situation of the polar front indicated by an arrow on the right, while the stations on the left.

The swimming layer of the pollack is generally $130-150 \mathrm{~m}$ to $200-250 \mathrm{~m}$ in the south of the polar front, while it is much shallower, $20-30 \mathrm{~m}$ to $100-200 \mathrm{~m}$, in the north of the front.

sharply separated from each other vertically regardless of their habitats, demersal or pelagic ${ }^{3)}$, and that the boundary between these faunas is rather constantly maintained near the $150 \mathrm{~m}$ level in the southern and southeastern part of the sea at the least.

Before closing this section, it must be added that the vertical segregation of the northern and southern elements mentioned above is neither typically observable throughout the year nor thoughout the entire area of the Japan

3) For this reason, the horizontal distribution patterns of the northern and southern elements were treated quite separately in Section 3.1, neither interactions nor interrelations between them being referred to. 
Sea. In some parts of the sea in certain seasons, especially from late winter to spring, some of the northern cold-water elements make appearance in the surface layer replacing the southern elements, as already discussed in Sections 3.6 and 3.7 on the nektonic and planktonic communities. Either, the typical vertical segregation of northern and southern elements can not be observed in the northern and northwestern parts of the Japan Sea, where the southern elements are only poorly represented since the majority of the warm-water animals are limited of their northward distribution beyond the belt extending across the Japan Sea from the southeastern corner of Korea Peninsula to near the western entrance to the Tsugaru Straits (cf. Fig. 2 in Part I). Especially, most members of the "okaba" bottom communities fail to penetrate into these northerly waters (refer the species lists and the compositions of the catches of commercial or experimental trawlings off northwestern Hokkaido, west Sakhalin and the Maritime Province which were compiled respectively by Kitano \& Kanamaru 1960 ; Hokkaido Fish. Exper. Stat. 1956; MoISeEv 1953); again Meshcheryakova (1960) states that the distributions of the bulk of the typical tropical plankters are confined to the south of $40^{\circ} \mathrm{N}$. in the central part of the Japan Sea even at the peak of their northward extension in late summer to autumn. The southern elements that occur in those northerly waters are mainly composed of (1) warm-temperate to tropical migratory or epipelagic animals (cf. Sections 3.1 and 3.8; also Schmid 1926), (2) warm-water neritic forms, especially of the planktonic life (cf. Sctions 3.3 and 3.7 ; also BroDSky 1957: 164), and (3) certain mesopelagic forms like Mola mola in nekton and Calanus tenuicornis and Eucalanus attenuatus in plankton (Novikov 1957b; Brodsky 1950, 1957, 1959; Ponomareva 1959 ; etc.). Limited numbers of these southern elements appear as a rule only during a short period of the summer and in a quite shallow layer, for instance less than $25-30 \mathrm{~m}$ in Peter the Great Bay and adjacent waters; below this depth in summer and throughout the whole strata in other seasons these northerly waters are inhabited by thriving northern cold-water forms.

\section{10. Faunal Zonation on the "Okaba" and "Taraba" Grounds}

Our knowledge of the characteristic animals on the "okaba" and "taraba" grounds, the major categories of the bottom environments in the Japan Sea, depends largely on the products of trawling or other demersal fisheries for commercial purpose. The commercial fisheries products, however, comprise only the species of market value and those of no commercial value caught together with useful ones are usually thrown into the sea and only rarely brought to the market to be examined by us; moreover, the commercial trawling is legally inhibited in most districts of Japan to be operated in the very inshore zones of smaller depths, generally within 3 nautical miles from the coast or less than 70 or $80 \mathrm{~m}$ in depth. The deficiency thus confronted, 
however, can fortunately be supplied by the results of the non-commercial and investigational trawlings or dredgings such as those carried out by several prefectural fisheries experimental stations on the entire offshore grounds and on the banks in the Japan Sea in 1955-1957 (Fisheries Agency, Japan 1958c), those by Watanabe et al. (1960) off San'in District in 1956, and those by Ouchi (1960), Ouchi \& Ogata (1960a, 1960b), Yamagata Prefectural Fisheries Experimental Station (1962, 1963) and Shimane Prefectural Fisheries Experimental Station (1963) in the shallow coastal waters off Niigata, Yamagata and Shimane Prefectures respectively in the years 1958-1959, 1961 and 1962. Further we have some data of underwater observations by SCUBA diving in the inshore waters on rocky coasts (OKuno \& Nonogami 1966). Analyses on the data of these investigations together with those of the commercial fisheries seem to be enough to give us some distinct ideas concerning the characteristic composition and distribution of respective bottom communities in the eastern and southern parts of the Japan Sea.

Looking through the results of the commercial catches and of the investigational trawlings and dredgings made at various spots of different depths throughout the so-called "okaba" and "taraba", there may be perceived a trend toward the existence of still more detailed structures arranged vertically in the bottom communities, namely, at least seven distinct animal communities, four on the "okaba" and at least three on the "taraba", being recognized in the bottom environments in most of the southeastern parts of the Japan Sea. Each community is characterized by its distinctive faunai composition and its regular situation in the vertical distribution, as seen typically in Fig. 24 (p. 366), which illustrates the vertical ranges of some principal demersal fishes off the coast off Niigata and Yamagata Prefectures. These subdivided communities are named in this paper respectively okaba communities $I, I I, I I I$ and $I V$, and taraba communities $I, I I$ and $I I I$ in the order from shallower to deeper locations; and their faunistic and zoogeographical aspects will be given briefly next.

The okaba community I, or the community at the shallowest level, is noted by the occurrences of many species which are originally the inhabitants of embayment or neritic environments of the tropical to subtropical regions; the development of such populations, generally restricted in the inner part of bays or lagoons in other seas, even in the open or exposed area of the coast is a remarkable feature of the Japan Sea. The okaba community II, on the other hand, is represented by a subtropical to warm-temperate fauna of moderately deep environments and characterized, among others, by the occurrences of many red-pigmented fishes such as snappers (Chrysophrys, Evynnis, Taius, etc.), gurnards (Lepidotrigla), horse-head (Branchiostegus) and band-fishes (Cepola and Acanthocepola) which are called "aka-mono" or redçolored fishes by fishermen. The leading species of thes two communities met 
with most frequently and abundantly in the eastern and southern bottom of the Japan Sea are:

\section{The okaba community I}

Pisces

*Apogon spp.

*Upeneus bensasi

*Callionymus spp.

*Nemipterus virgatus

Oplegnathus fasciatus

*Leiognathus spp.

Chrysophrys major (young stage)

Evynnis japonica (young stage)

*Siganus fuscescens

Halichoeres tenuispinis

${ }^{*} H$. poecilopterus

*Semicossyphus reticulatus

Goniistius spp.

*Therapon spp.

Parapristipoma trilineatum

Hapalogenys spp.

Plectorhynchus cinctus

Trichiurus lepturus (young stage)

Zeus japonica (young stage)

*Sillago japonica

* Girella punctata

* Mugil cephalus

Chelidonichthys kumu

*Saurida undosquamis

Sphyraena pinguis

*S. japonica

*Stephanolepis cirrhifer

Navodon modestus

* Fugu spp.

*Chaeturichthys hexanema

Ditrema temmincki

Chromis notatus

*Sebastes inermis

*S. joyneri

*Hypodytes rubripinnis

*Trachinocephalus myops

*Heteromycteris japonicus

*Aseraggodes kobensis

* Paraplagusia japonica

Cynoglossus robustus

*Zebrias zebra

Areliscus joyneri

Laeops lanceolatus

*Pseudorhombus cinnamoneus

$P$. pentophthalmus (mainly young stage)
*Engyprosopon grandisquama

Rhinobatos schlegeli

*Mustelus manazo

*Triakis scyllia

Echinodermata

*Pseudocentrotus depressus

Anthocidaris crassispina

* Temnopleurus toreumaticus

Peronella japonica

Lovenia elongata

* Schizaster lacunosus

* Pseudomaretia alta

Ophioplocus japonicus

Ophiarachnella gorgonia

Astropecten scoparius

Coscinasterias acutispina

*Asterina batheri

Certonardoa semiregularis

*Holothuria monacaria

Mollusca

*Octopus ocellatus

O. vulgaris

*Sepia spp.

* Euprymna morseri

Cellana toreuma

Monodonta labio

Serpulorbis imbricatus

Tegula lischkei

T. pfeifferi carpenteri

*Littorina brevicula

Nodilittorina granularis

Aplysia parvula

A. kurodai

Glossodoris festiva

G. pallescens

G. florens

Elysia abei

Dendrodoris nigra

Dermatobranchus striatus

Dosinia japonica

Mactra sulcataria

Macoma incongrua

* Mya arenaria

Septifer spp.

Ischnochiton comptus

Crustacea

*Hemigrapsus sanguineus 
Goetice depressa

Thalamita sima

* Charybdis japonica

Ch. bimaculata

* Paratymolus pubescens

Leucosia longifrons

* Trigonoplax unguiformis

Lyreides tridentatus

Lambrus validus

Matuta spp.

Myra fugax

Ovalipes punctatus

* Portunus trituberculatus

$P$. gladiator

Pagurus samuelis

$P$. japonicus

Hippa truncatifrons

*Palaemon serrifer
* Alpheus japonicus

* Heptacarpus propugnatrix

* Leptochela gracilis

Pandalus meridionalis

*Metapenaeopsis acclivis

* Atypopenaeus compressipes

* Squilla oratoria

Polychaeta

Spirorbis foraminosus

Sabellastarte indica

Acrocirrus validus

* Arenicola brasiliensis

Coelenterata

*Aglaophenia whiteleggei

Sertularella miurensis

Anthopleura asiatica

A. japonica

Actinia equina

\section{The okaba community II}

Pisces

Lepidotrigla spp.

Chrysophrys major

Evynnis japonica

Taius tumifrons

Döderleinia berycoides

Niphon spinosus

Trichiurus lepturus

Zeus japonicus

Uranoscopus japonicus

Neobythites sivicolus

Branchiostegus japonicus

Parapercis spp.

Argyrosomus argentatus

Cepola schlegeli

Priacanthus boops

Chaeturichthys sciistius

Pseudorhombus pentophthalmus

Eopsetta grigorjewi

Tanakius kitaharai

Hime japonica

Lophius litulon

Raja kenojei

$R$. tengu

Dasyatis akajei

Ascidia

Syndiazona grandis

Echinodermata

Stereocidaris japonica

Planilampas sternopetala
Peronella rubra

Luidia maculata

Mediaster brachiatus

Dipsacaster pretiosus

Parastichopus nigripunctatus

Mollusca

Doryteuthis kensaki

Acila divaricata

Dosinia angulosa

Glycymeris rotunda

Limopsis tajimae

Siphonalia spadicea

S. fusoides

Crustacea

Latreillia phalangium

L. valida

Carcinoplax longimanus

C. vestita

Leptomithrax edwardsii

Ebalia japonica

Aniculus aniculus

Ceratopagurus pilosimanus

Munida japonica

Ibacus ciliatus

Crangon affinis

Polychaeta

Terebella ehrenbergii

Thelepus toyamaensis

Coelenterata

Bellonella rigida 
The inhabitants of the embayment or the neritic environment found in the species list of the okaba community I are marked with an asterisk. Off the coast of Niigata and Yamagata Prefectures, for instance, the most dominant species in this community are Leiognathus rivulatus, Callionymus spp., Upeneus bensasi, Stephanolepis cirrhifer, Chaeturichthys hexanema, Apogon lineatus, A. kiensis, A. semilineatus, etc. of fishes and Metapenaeopsis acclivis, Atypopenaeus compressipes, Alpheus japonicus, Squilla oratoria, etc. of crustaceans (OucHi 1960; Ouchi \& Ogata 1960a; Yamagata Pref. Fish. Exper. Stat. 1962, 1963). These are all typical embayment inhabitants; some of them such as the fishes of the genera Leiognathus (L. rivulatus and nuchalis), Apogon (A. lineatus, kiensis, etc.) and those of the families Callionymidae and Gobiidae (Chaeturichthys hexanema and sciistius, Rhinogobius phaumi, etc.) are known to constitute together with the anchovy Engraulis japonica and a trachinoid fish Champsodon snyderi the most important part of the food for the predatory fishes in the Seto Inland Sea (Hayashi \& Yamaguchi 1960), while Metapenaeopsis acclivis is abundantly found in the Seto Inland Sea and Ise Bay, Atypopenaeus compressipes in the Seto Inland Sea and Ariake Bay, and Alpheus japonicus abounds in many bays of southern to middle Japan (Kubo [\& NAKAzAwA] 1947 ; OuchI 1960). The rich occurrence of embayment species in the okaba community I must be the reflection of the peculiar hydrographical condition of shallow layers in the Japan Sea ${ }^{4}$.

In this connection, it seems a remarkable fact that many of the animals inhabiting the tropical-subtropical rocky or coral reefs and commonly observed on the exposed shores on the Pacific side of the southern and central Honshu are quite poor or missing altogether in the Japan Sea. As typical examples of such animals we can cite the following: butterfly-fishes (Chaetodontidae) ${ }^{5}$, surgeon-fishes (Acanthuridae) ${ }^{6}$, silversides (Atherinidae), rock cod (Epinephelus),

4) From his studies on the algal communities in the surrounding seas of Japan, TANIGUTI (1961) concludes that the sea-weed communities developed on the coast of the Japan Sea, even on its exposed part, are of an inland-sea or sheltered-shore type in physiognomy and in composition, forming a conspicuous contrast with the situation found on the Pacific side of Japan.

5) For instance, about 24 species of butterfly-fishes are known in Tanabe Bay on the Kii Peninsula in central Honshu facing the Pacific; and a species of them, Chaetodon collaris, is well established and thriving there (OKUnO 1964). According to YASUDA \& MATSUOKA (1962), more than 10 species of butterfly-fishes are found in Sagami Bay, of which Chaetodon auriga, melanotus and ephippium are commonly observed together with $C h$. collaris. In the Japan Sea, on the other hand, only 4 species are so far recorded and all of them seem to be of sporadic occurrence; of these, a species, Ch. modestus, is known from a comparatively wide range from San'in District to Yamagata Prefecture, while $C h$. collaris has been recorded only once in San'in District (MORI 1956) and no record at all for $C h$. auriga, melanotus and ephippium.

6) Five species of surgeon-fishes are known from Tanabe Bay, of which Prionurus microlepidotus is quite abundant and flourishing there (Okuno 1964). On the other hand, this species seems rare in the Japan Sea (HoNma 1957b, 1957c ; Novikov 1957a) and constitutes together with Acanthurus triostegus, an even rarer species, the acanthurid fauna of the Japan Seạ, 
silver-bellies (Gerres), flag-tail Kuhlia taeniura, cardinal-fishes Apogon notatus and döderleini ${ }^{7}$, etc. of fishes; Diadema setosum, Echinostrephes aciculatus, Tripneustes gratilla, Echinometra mathaei, etc. of sea-urchins ; spiny lobsters (Panu(irus) ${ }^{8)}$, Stenopus hispidus, etc. of decapod crustaceans.

Of the remaining two communities on the lower part of the "okaba" ground, the okaba community III is characterized by the inclusion of many sublittoral forms of temperate region as shown below:

\section{The okaba community III}

Pisces

Hexagrammos otaki

Agrammus agrammus

Pseudoblennius percoides

Ammodytes personatus

Enedrias nebulosus

Dictyosoma burgeri

Paralichthys olivaceus

Kareius bicoloratus

Limanda yokohamae yokohamae

L. herzensteini

Echinodermata

Scaphechinus mirabilis

Hemicentrotus pulcherrimus

Asterina pectinifera
Asterias rollestoni

Henricia nipponica

Stichopus japonicus

Paracaudina chilensis ransonnetti

Mollusca

Loligo budo

L. edulis

Tellina nebulosa

Chlamys nipponensis

Crustacea

Spirontocaris geniculata

Pachygrapsus crassipes

Pugettia quadridens

Pinnixa rathbuni

Hapalogaster dentata

These are originally coastal demersal species; but in the eastern and southern parts of the Japan Sea they usually inhabit the area of a considerable water depth except for a certain season of the year. For instance, the mud-dab Limanda herzensteini is said to live usually in the depths $100-150 \mathrm{~m}$ off the coast of Niigata Prefecture, but it makes appearance in the coastal

7) As mentioned previously in the text, the predominant species of the cardinal-fishes in the Japan Sea are Apogon lineatus, kiensis and semilineatus. Meanwhile, the most common species in Tanabe Bay on the Pacific coast is $A$. notatus followed by $A$. döderleini and semilineatus (Okuno 1964); of these, A. notatus and doderleini, both quite missing in the fish fauna of the Japan Sea, inhabit usually the shallower rocky reefs and $A$. semilineatus together with $A$. lineatus is found on a deeper sandy bottom in the inner part of the bay (personally communicated by Ch. ARAGA in October, 1965).

8) Six species of spiny lobsters are known from the Kii Peninsula, of which Panulirus japonicus is very abundant on the rocky reefs (HARADA 1965). The spiny lobsters are considered exceedingly rare or totally absent in the Japan Sea. Certain species of the scyllarid lobsters, on the other hand, are found not infrequently in the Japan Sea, especially in its southern part; for instance, Scyllarus bicuspidatus and kitanoviriosus and Ibacus ciliatus and novemdentatus are recorded from the bottoms off San'in District to Sado Island (KAWANA 1941 ; KIKUCHI ?; NISHIMURA \& YAMAZAKI 1961; IWASAWA 1962; HARADA 1962 ; Harada \& Holthuis 1965 ; etc.). According to Harada (1965), these scyllarid species generally live on the sandy bottom somewhat more deeply situated than the racky reefs which ạre inhabịted by the spiny lobsters, 
zone shallower than $60 \mathrm{~m}$ for the spawning during a short period in early spring; after the spawning season is over, this fish again disappears in the shallow coastal waters (OUCHI \& OGATA 1962). By the experimental trawlings made by WAtanabe et al. (1958) off San'in District, L. yokohamae yokohamae was caught at $200 \mathrm{~m}$ in October, at $150 \mathrm{~m}$ in January and at $100 \mathrm{~m}$ in March ; this may indicate a trend of the migration toward the shallower places with the approach of spawning season. The same is for greenlings Hexagrammos otaki and Agrammus agrammus; both appear in shallow coastal zones only during the spawning season in winter, in other seasons they hide themselves in comparatively deep bottoms. Hexagrammos otaki and rockfish Enedrias nebulosus were caught by the experimental trawlings operated by Yamagata Prefectural Fisheries Experimental Station (1962) off the coast of northern Honshu at the places of $50-150 \mathrm{~m}$ and $100-150 \mathrm{~m}$ deep respectively during the warm season of the year; the latter species was also recorded at $200 \mathrm{~m}$ and occasionally at $300 \mathrm{~m}$ off the coast of San'in District (WATANaBE et al. 1958). The sand-lance Ammodytes personatus, another member of the present community, also moves to some protected shallow places during the spawning in winter to lay demersal eggs, and it is said to go back to deeper offshore floors after the spawning is over and then to spend the rest of the year possibly burying itself in sand (Онsнima 1950). As for the invertebrate fauna, the starfish Asterina pectinifera may be cited: this species is quite commonly seen around the low-tide levels on the coasts from Hokkaido to Kyushu, but it is also observed to inhabit considerable depths, for instance 200-300 $\mathrm{m}$ in Ryotsu Bay of Sado Island (HAYASH 1957). The same may be true for Asterias rollestoni, too.

Taking these aspects in consideration, the community may be expressed as a "temperate sublittoral fauna", characterized by a marked vertical migration or a wide range of vertical distribution of its component species.

The okaba community IV is represented by a very distinct fauna. Though its specific composition is rather simple, several remarkable and important species are included; the main commercial species in this community and the species possibly inhabiting there because of their appearances in the stomach contents of those commercial animals are listed below :

\section{The okaba community IV}

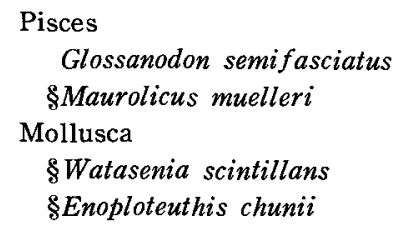

\&E. theragrae
Crustacea
Parathemisto japonica
\$Metridia pacifica
\$Euphausia pacifica
Pasiphaea sivado

It is peculiar that some phylogenically old species well adapted to the 
deep-sea life and sometimes equipped with luminous organs (the luminescent species are marked with the sign $\$$ on the above list) are included here; they are essentially oceanic and warm-water species, though some are secondarily adapted to the life more or less restricted to the edges and slopes of the continental shelf (Glosssanodon, Maurolicus, Pasiphaea, etc.). Moreover, most of the members are remarkably flourishing, playing an important part in the bio-economy of the Japan Sea (Nishimura 1957a, 1959b, 1964d; WATAnabe et al. 1958; Shimomura \& Fukataki 1957; Bowman 1960; Fukataki 1960a, Fukataki et al. 1961; Ponomareva 1962; Okiyama 1965; etc.)

Then, on the "taraba" ground at least three communities are subdivided. Of these, the uppermost one or the taraba community $I$ is composed of the elements fundamentally of a subarctic sublittoral nature, and hence it may be called as a "subarctic sublittoral community". It is represented by the following :

\section{The taraba community I}

Pisces
Pleurogrammus azonus
Sebastes thompsoni
S. nivosus
S. taczanowskii
Aptocyclus ventricosus
Certain species of the subfamily
Liparinae
Most species of the family Agonidae
and the subfamily Opisthocentrinae
Stichaeus grigorjewi
Cleisthenes pinetorum herzensteini
Limanda aspera
L. yokohamae schrencki
L. punctatissima punctatissima
Glyptocephalus stelleri
Clupea harengus pallasi
Echinodermata
Strongylocentrotus nudus
Scaphechinus griseus
Asterias amurensis
Henricia reticulata
Distolasterias nippon
Plazaster borealis
Ophiura sarsi var. vadicola

Diamphiodia craterodmeta
Cucumaria japonica
Mollusca
Eunucula tenuis
Philine japonica
Modiola modiolus
Chlamys swifti
Yoldiella johanni
Turritella fortilirata
Crustacea
Telmessus acutidens
Pisoides bidentatus
Cancer amphioetus
Hyas coarctatus alutaceus
Oregonia gracilis
Pagurus ochotensis
Polychaeta
Abarenicola pacifica
Serpula vermicularis
Maldane sarsi
Scoloplos armiger
Polydora coeca
Rhodine gracilior
Coelenterata
Metridium senile var. fimbriatum

These animals found at considerable depths, $150-250 \mathrm{~m}$ and mostly around $200 \mathrm{~m}$, in the eastern and southern regions (Watanabe et al. 1958, 1960; Ouchi \& OGATA 1962) inhabit the shallow (5-60 m) coastal zones in the northern and and northwestern regions of the Japan Sea (MoIseev 1953; Zenkevitch 1963).

The taraba communities II and III are the principal communities on the 
"taraba" ground, as they occupy respectively a large space and support a great biomass. The separation of these two communities is mainly based on the results of studies by WATANABE et al. (1958), who discriminated two major associations in the demersal fish populations on the "taraba" ground off San'in District, one being predominated by the dab Hippoglossoides dubius, and the other characterized by an overwhelming occurrence of the eelpout Allolepis hollandi. The former comprises Glyptocephalus stelleri, Cleisthenes pinetorum herzensteini, Arctoscopus japonicus, Sebastes owstoni, Gadus morhua macrocephalus and Theragra chalcogramma as subdominant fishes and the main level of occurrence is found at $200-300 \mathrm{~m}$; while the subdominant members of the latter association are Hippoglossoides dubius and occasionally Petroschmidtia toyamensis or Breviraja smirnovi which, together with the eelpout, are found mainly at the depths more than $300 \mathrm{~m}$. A similar vertical segregation was also noted by WATANABE et al. (1960) for the benthonic invertebrate fauna: the invertebrate populations on the "taraba" ground seem to be divided into two groups; the group inhabiting the shallower place, approximately $200-300 \mathrm{~m}$, is characterized by rich occurrences of king crab Chionoecetes opilio elongatus, prawns Lebbeus groenlandicus and Pandalus hypsinotus, brittle-star Stegophiura sterea, etc., while that inhabiting the deeper levels, $350-400 \mathrm{~m}$ or more, is characterized by the dominancy of prawns Crangon dalli, Nectocrangon toyamensis and Pandalus borealis and a crinoid Pentametrocrinus $\mathrm{sp}^{9}$. A similar zonation on the "taraba" ground may be observed in more northerly regions such as the area off Niigata and Yamagata Prefectures (A. Ouchi, personal communication); further, the Arctoscopus japonicus association and the Pandalus borealis association noted by OKACHI (1954) as the two main associations found in the demersal communities in the Sado Straits may be regarded as corresponding respectively to the above-mentioned two taraba communities.

Thus, the taraba communities II and III are represented by the following species :

\section{The taraba community II}

Pisces

Arctoscopus japonicus

Theragra chalcogramma
Gadus morhua macrocephalus

Hippoglossoides dubius

Sebastes owstoni

9) The trawlers of San'in District know that the fishing ground of the king crab Chionoecetes opilio elongatus is frequently accompanied with the brittle-star population, while the big catches of the prawn Pandalus borealis, another object of commercial value, are always linked with rich occurrences of crinoid species; and that the prawn ground is much deeper than the king crab ground. The spots where these commercial items are found densest are called by them " $m e$ " (eye or center), and the arrangement of " $m e$ " of different species on the "taraba" ground is found in the following order from the coast to the offing, or with the increase of the water depth:

"Me" of Cleisthenes pinetorum herzensteini $\rightarrow$ "Me" of Chionoecetes opilio elongatus $\rightarrow$

"Me" of Hippoglossoides dubius $\rightarrow$ "Me" of Pandalus borealis. 


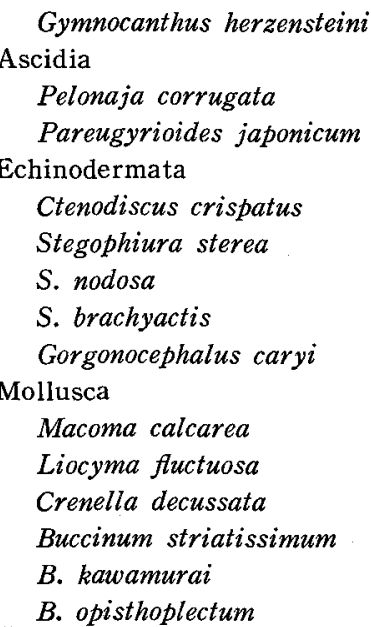

Neptunea intersculpta

Crustacea

Chionoecetes opilio elongatus

Erimacrus isenbeckii

Pagurus cavimanus

Pandalus hypsinotus

Pandalopsis japonica

Lebbeus groenlandicus

Ampelisca macrocephala

Haploops laevis

Polychaeta

Prionospio steenstrupi

Euchone olegi

Travisia forbesii

Asychis punctata

Coelenterata

Stomphia coccinea

\section{The taraba community III}

$\begin{array}{lc}\text { Pisces } & \text { B. tenuissimum } \\ \text { Allolepis hollandi } & \text { Neptunea constricta } \\ \text { Petroschmidtia toyamensis } & \text { Volutopsis furukawai } \\ \text { Lycodes tanakai } & \text { Verticordia nadina } \\ \text { L. nakamurai } & \text { Yoldiella derjugini } \\ \text { Davidijordania poecilimon } & \text { Octopus dofleini } \\ \text { Lumpenus macrops } & \text { Crustacea } \\ \text { Lumpenella longirostris } & \text { Chionoecetes japonicus } \\ \text { Malacocottus gibber } & \text { Crangon dalli } \\ \text { Triglops scepticus } & \text { C. communis } \\ \text { Dasycottus spp. } & \text { Nectocrangon toyamensis } \\ \text { Icelus spp. } & \text { Pandalus borealis } \\ \text { Breviraja smirnovi } & \text { Syrrhoe crenulata } \\ \text { Echinodermata } & \text { Socarnes bidenticulatus } \\ \text { Heliometra glacialis maxima } & \text { Anonyx nugax } \\ \text { Pentametrocrinus sp. } & \text { Polychaeta } \\ \text { Ophiura sarsi sarsi } & \text { Aphrodita sp. } \\ \text { Amphioplus macraspis } & \text { Amage asiaticus } \\ \text { Ctenodiscus crispatus } & \text { Lumbriconeris fragilis } \\ \text { Crossaster papposus japonicus } & \text { L. japonica } \\ \text { Pseudarchaster parelii } & \text { Scalibregma inflatum } \\ \text { Mollusca } & \text { Coelenterata } \\ \text { Buccinum rossicum tsubai } & \text { Liponema multicornis } \\ & \end{array}$

Now there remain two things to be learned: (1) how further the taraba community III extends downward, and (2) if there are any particular bottom communities of the distinct faunal composition below the taraba community III in the Japan Sea. Next are made some discussions upon these questions on a little knowledge available at present.

The training ship Umitaka Maru of the Tokyo University of Fisheries 
Eulalia bilineata

E. sigeformis

E. sanguinea

E. tubiformis

E. nigrimaculata

Eteone barbata

E. bistriata

E. ornata

Aphrodita australis

Lepidonotus squamatus

I. belotypus

Hololepidella tuta

H. semenovi

Polynoë tarasovi

Nemidia torelli

Harmothoë aspera

H. impar grandispine

H. impar parvispinosa

H, derjugini

Sigalion mathildae

Syllis spongicola

S. heterochaeta

S. oerstedi

Pionosyllis magnifica

Exogone tatarica

Autolytus caterinkae

Cheilonereis cyclurus

Nephthys caeca

Euphrosyne bicirrata

E. hortensis

E. superbe

Eunice kobiensis

Lumbriconereis heteropoda

Staurocephalus moniloceras SEDENTARIA

Aricia norvegica

Laonice cirrate

Polydora quadrilobate

F. nova

P. malmgreni

P. steenstrupi

Aricidea lyriformis

A. ramosa

A. uschakovi

Chetopterus variopedatus

Cirratulua cirratus

Heterocirrus alatus maculatus

Tharyx pacifica

Chaetozone setosa

Acrocirrus heterochaetus

Plabelligera affinis

Diplocirrus longisetogus

Brada Inhabilis

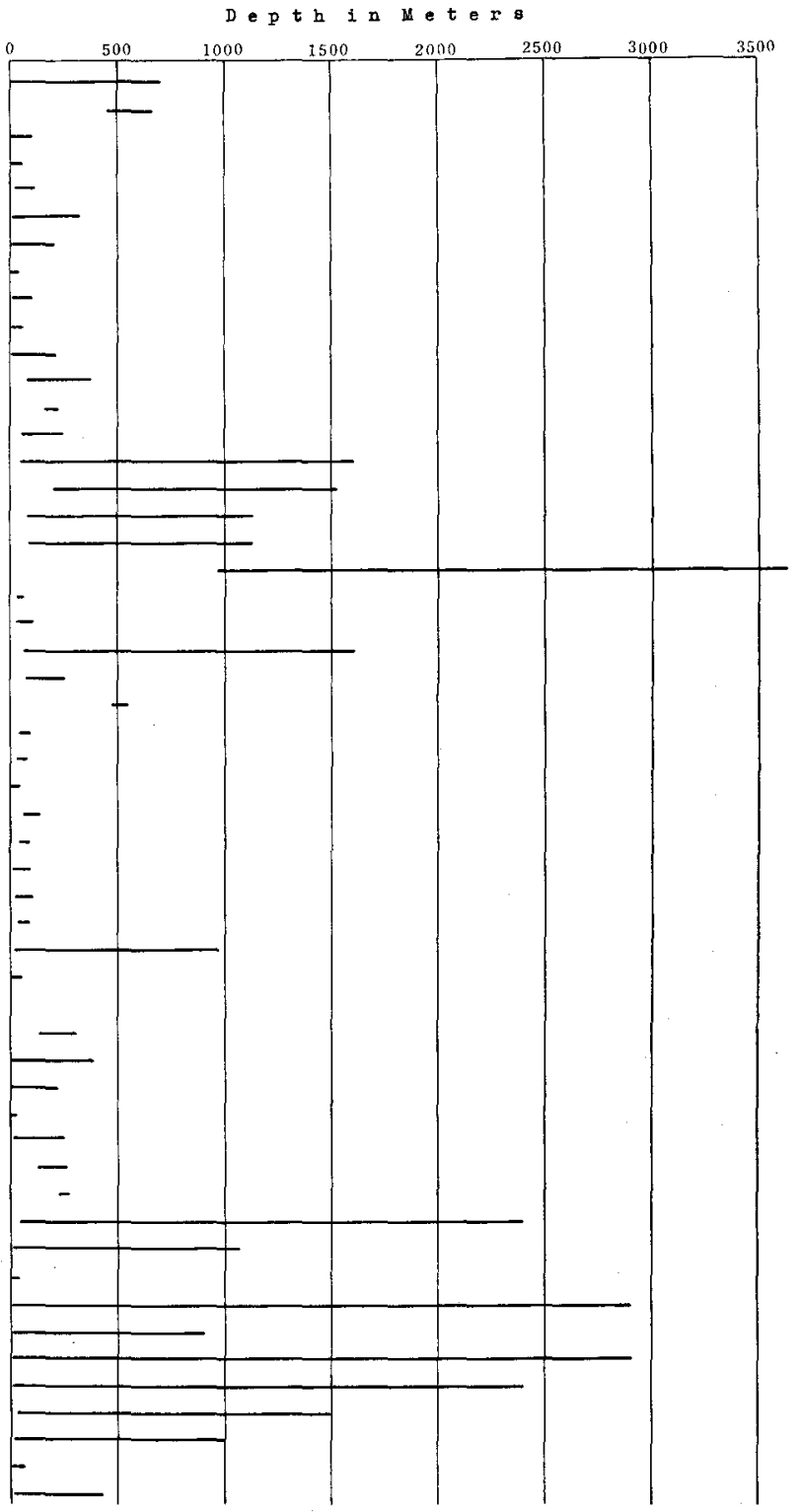

Fig. $27 a$

Legend on next page 
Species

SEDENTARTA (continued)

Scalibregma inflatum

Travisia kerguelensia intermedia

T. japonica

Notomsstus latericeus

Capitella capitata

Notoproctus oculatus

Petaloproctus tenuis

Nicomache minor

Microclymene pacifica

Axiothella catenata

Maldarella harai

Asychis disparidentata punctata

Myriochele heeri

M. pacifica

Melinne cristata

Melinnampharete eoa

Ampharete lindströmi

A. arctica

Anobothrus gracilis

Iysippe labiata

Schistocomus sovjeticus

Prichobranchus glacialis

Pista flexuosa

P. cristata

P. zachsi

P. incarrientis

$P$. foliferiformis

Neoamphitrite figulus

N. groenlandica

Amphitrite cirrata

Leaena abranchiata

Proclea emmi

Laphania boecki

Lanassa venusta venusta

I. venusta pacifica

Artacama proboscidea

Streblosoma bairdi

Polycirrus eous

P. medusa

Lysilla loveni

Sabella fabricii

Jasmineir pacifica

Euchone papillosa

Myxicola infundibulum

Spirorbis coronatus

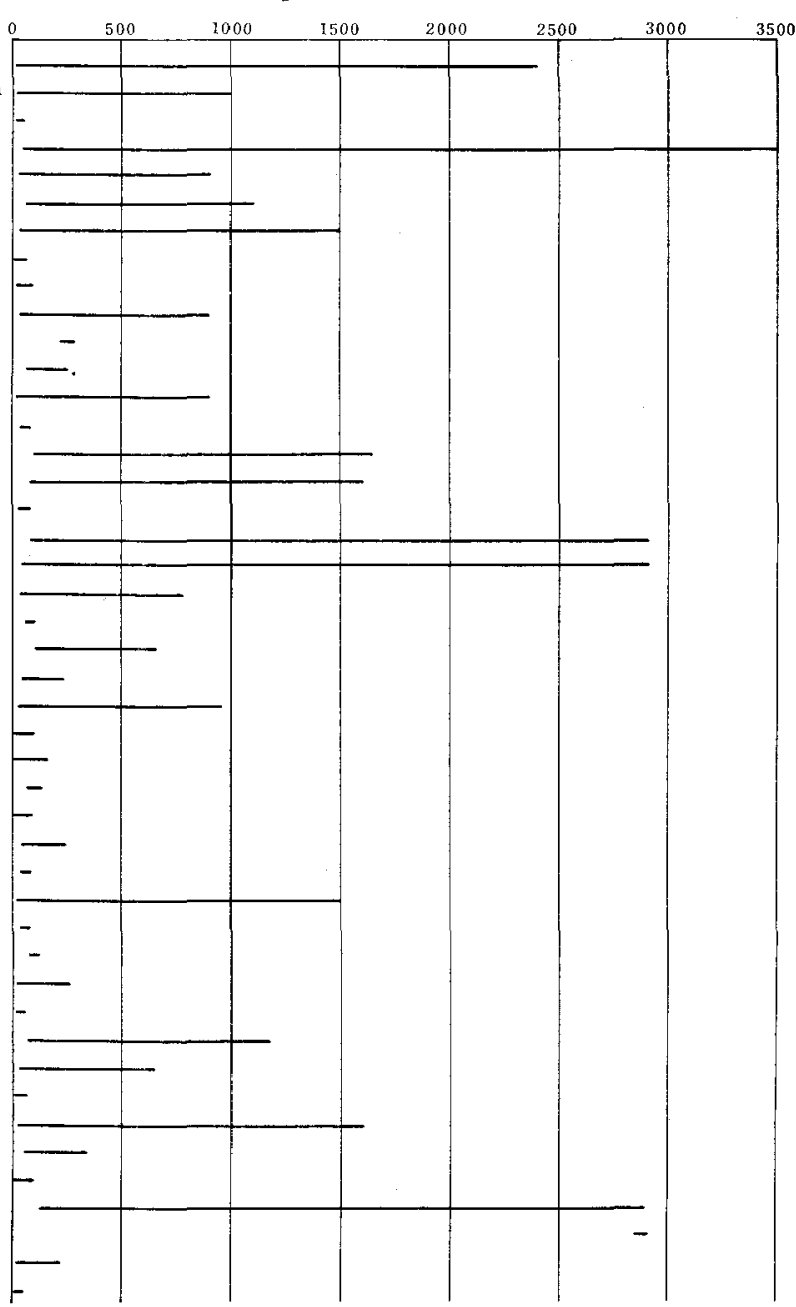

Fig, $27 b$

Fig. 27. Bathymetric representation of living ranges of polychaetes in the Japan Sea. (After Uschakov 1955).

made a deep sea beam-trawl on August 14, 1963, on the $930 \mathrm{~m}$ deep bottom at $37^{\circ} 06^{\prime}$ N., $134^{\circ} 36^{\prime} \mathrm{E}$. near the Oki Bank in the southern Japan Sea. The result of the one-hour trawling was kindly informed me by Captain $\mathrm{K}$. OzAwa, and it was shown that the catch was composed of 50 Allolepis hollandi, some Lycodes nakamurai, 10 Malacocottus gibber, 5 Chionoecetes japonicus, two species of starfishes and some gastropods, mostly belonging to the Buccinidae. Further, Captain Ozawa mentioned that a similar trawling was made in the summer of 1962 on the $800 \mathrm{~m}$ bottom off Yoichi, west Hokkaido, with 
the result of obtaining the catch of quite similar composition in quality and quantity. Then, the composition mentioned above is nothing but that of the taraba community III referred to just above; thus, it is possible that the taraba community III extends downward at least to $800-900 \mathrm{~m}$. Moreover, certain members of the taraba community III are known to be distributed further downward: for instance, the starfish Ctenodiscus crispatus is known down to $1200 \mathrm{~m}$ (MoKievsky 1954) or $2000 \mathrm{~m}$ (Djakonov 1958), the bivalve Yoldiella derjugini to $1770 \mathrm{~m}$ (MoKIEvsky 1954), the king crab Chionoecetes japonicus (=Ch. angulatus bathyalis) to $2530 \mathrm{~m}$ (Mokievsky 1954), the polychaetes Scalibregma inflatum and Amage asiaticus respectively to $2400 \mathrm{~m}$ and $2900 \mathrm{~m}$ (UschaKov 1955), etc. These records seem to suggest that the taraba community III is extending as deep as $2500-3000 \mathrm{~m}$ or presumably to $3600 \mathrm{~m}$, that is, the deep bottom plain of the Japan Sea.

There are but a few faunistic works with the bathymetric data of the living ranges of many of the species concerned. The contribution of UschAKov (1955) on the polychaete fauna of the Far Eastern seas is one of such a few works; and borrowing his data the vertical distribution pattern of the members of this animal group occurring in the Japan Sea with known bathymetric ranges is shown in Fig. 27. This figure seems to indicate the following tendencies :

(1) Many of the species ever penetrating into a considerable depth, say, below 200-300 $\mathrm{m}^{10)}$, generally continue to distribute downward to $1000-1500 \mathrm{~m}$, while only a small number of them descend further to greater depth.

(2) The species confined exclusively to the depths greater than 1000 $1500 \mathrm{~m}$ is very scarce; Harmothoë derjugini, an endemic scale-bearing worm with eyes quite degenerated, is the only species known to belong definitely to this category.

These facts seem to indicate that there is not any animal community of distinct faunal property on the bottoms deeper than $1000-1500 \mathrm{~m}$ but that the animal community found there is better to be regarded as representing the depauperated fauna near the lower periphery of the distribution of the taraba community III. Of course, this conclusion made only on the limited data available at present may be subject to alteration by further knowledges to be accumulated on the distribution of the deep-water faunas in this sea basin.

\section{[To be continued]}

10) Note that this is the depth of the upper margin of the taraba community III throughout the Japan Sea (cf. Section 3.11 to be included in the forthcoming paper of this series). 